\title{
Diagnostic Role of FNAC in Evaluation of Head and Neck Lesions
}

\author{
Modi M.H. ${ }^{1}$ Kokani M.J. ${ }^{2}$ \\ ${ }^{1}$ Dr. Mayuree H. Modi, Tutor, Department of Pathology, GMERS Medical College and Hospital Gotri, Vadodara, \\ ${ }^{2}$ Dr. Mayur J. Kokani, Assistant Professor, Department of Pathology, GMERS Medical College and Hospital, Junagadh, \\ Gujarat, India.
}

Corresponding Author: Dr. Mayur J. Kokani, Assistant Professor, Department of Pathology, GMERS Medical College and Hospital, Junagadh, Gujarat, India. E-mail: mkokon11@gmail.com

\begin{abstract}
Introduction: The neck masses are relatively common problem. These neck masses are evaluated by history, clinical examination and investigation like FNAC, USG neck, CT Neck and excision biopsy. Fine Needle Aspiration Cytology (FNAC) is a very simple, quick, inexpensive and minimally invasive technique used to diagnose different types of swellings in head and neck region. Objective: To assess the frequency and incidence of different sites, age, sex and distribution of reactive, benign and malignant lesion. Methods: A retrospective study was conducted at GMERS Medical College \& Hospital, Gotri, Vadodara, Gujarat from April 2018 to November 2018. Patients between the ages of 1 to 90 years were enrolled into the study. A total of 305 patients with a head and neck swelling underwent FNAC. Fine needle aspiration diagnosis was correlated with detail of relevant clinical findings and investigations. USG Neck was done in all cases prior to FNAC examination. Results: Out of 305 fine needle aspiration procedures $66.56 \%$ (203 cases) were of lymph node, $21.97 \%$ (67 cases) were of thyroid, 5.90\% from salivary gland (18 cases), 5.57\% (17 cases) from skin and subcutaneous swellings. Out of total 305 lesions, 239 (78.36\%) were inflammatory and benign, 66 (21.64\%) were malignant and metastatic carcinoma. Conclusions: Our study found that FNAC is simple, quick, inexpensive and minimally invasive technique to diagnose different types of head and neck swellings. It could differentiate the infective and benign process from neoplastic one and avoids unnecessary surgeries and expenses. Thus, FNAC can be recommended as a first line of investigation in the diagnosis of head and neck swellings.
\end{abstract}

Keywords: Head and neck Lesions, Fine Needle Aspiration Cytology, Benign and Malignant

\section{Introduction}

A lump is the most likely clinical problem to be encountered in the neck [1]. The evaluation of a neck mass is a common clinical dilemma and a condition to which clinicians routinely encounters [2].

The differential diagnosis in a patient presenting with neck mass is often extensive and will vary with age. These neck masses are evaluated by a detail history, clinical examination and investigation like FNAC, USG neck, CT Neck and excisional biopsy.

The common pathologies encountered in the neck presenting as a lump are lymphadenopathies (specific and non-specific, acute and chronic and reactive), metastatic carcinoma, lymphoma, thyroid swellings (goitre, nodules and cysts and carcinoma) and salivary gland swellings (sialadenitis, cysts, adenomas and carcinomas).

Manuscript received: $6^{\text {th }}$ December 2018 Reviewed: $17^{\text {th }}$ December 2018

Author Corrected: $22^{\text {nd }}$ December 2018

Accepted for Publication: $27^{\text {th }}$ December 2018
The less common pathologies presenting as swelling in the neck are carotid body tumour, Keratinous cyst, bronchial cyst, thyroglossal cyst, cystic hygroma, pharyngeal pouch and lumps of skin appendages [1]. Fine needle aspiration cytology is a simple, quick and inexpensive method that is used to sample superficial masses like those found in the neck and is usually performed in the outpatient clinic. It causes minimal trauma to the patient and carries virtually no risk of complications. Masses located within the region of the head and neck, including salivary gland and thyroid gland lesions can be readily diagnosed using this technique $[3,4]$.

FNAC is both diagnostic and therapeutic in a cystic swelling [5]. Fine needle aspiration cytology is helpful for the diagnosis of salivary gland tumours where it can differentiate between a malignant and a benign tumor with over $90 \%$ accuracy [6]. FNAC is particularly helpful in the work-up of cervical masses and nodules because biopsy of cervical adenopathy should be

Pathology Update: Tropical Journal of Pathology \& Microbiology Available online at: www.pathologyreview.in 572 | P a g e 


\section{Original Research Article}

avoided unless all other diagnostic modalities have failed to establish a diagnosis [7]. Fine needle aspiration cytology does not give the same architectural detail as histology but it can provide cells from the entire lesion as many passes through the lesion can be made while aspirating [8]. The purpose of this study was to seefrequency of distribution of various pathological conditions detected on FNAC in patients presenting with head and neck swellings and to evaluate the role of FNAC in their diagnosis. It emerges from the analysis that Fine needle aspiration cytology is a safe, simple and rapid method that can be done in diagnosing wide range of neck swellings.

\section{Material and Methods}

Place of the study: Blood Bank, Department of Pathology, GMERS Medical College \& Hospital, Gotri, Vadodara, Gujarat (India)

Type of the study: Retrospective

Sampling Methods: In this study, FNAC was performed in 305 patients presented with lesions in the head and neck regions, in Department of Pathology, GMERS Medical College \& Hospital, Gotri, Vadodara, Gujarat from April 2018 to November 2018. All patients were asked about history related to head and neck swelling and relevant questions to the etiological cause along with present, past and family history of tuberculosis and history of sexual exposure for syphilis and AIDS. Patients were explained about the procedure and its advantages and their written consent was taken. Fine Needle Aspiration Diagnosis was correlated with detailof relevant clinical findings and investigation. The technique was performed in the outpatient department with minimal trauma to the patient without any risk of complication.

The area to be aspirated was cleaned with spirit and a 22- 23 gauge needle was inserted at convenient angles to the lesions and multiple hits were made within the lesion with sufficient negative pressure; the needle was removed and the pressure was applied to the area of aspiration to avoid bleeding or hematoma formation. The material obtained was immediately fixed in $90 \%$ alcohol for routine haema-toxylin and eosin stain and Pap stain and few were air dried for giemsa stain.

Inclusion Criteria: All the age group of patients (0-90 years).

Exclusion Criteria: Lesions of oral cavities.

Statistical Analysis: Percentages were calculated for estimating frequency of various pathological conditions detected on FNAC in patients presenting with head and neck swellings.

\section{Results}

The study included 305 cases of the age ranged from 1 to 90 years (Table 1) out of which 147(48.20.\%) were males and 158(51.80.\%) were females (Table 2).

Table-1: Distribution of various lesions Age wise.

\begin{tabular}{|c|c|c|}
\hline Age (Years) & Cases & Percentage \\
\hline $00-10$ & 21 & $6.9 \%$ \\
\hline $11-20$ & 38 & $12.50 \%$ \\
\hline $21-30$ & 64 & $21.05 \%$ \\
\hline $31-40$ & 58 & $19.07 \%$ \\
\hline $41-50$ & 55 & $18.09 \%$ \\
\hline $51-60$ & 38 & $12.17 \%$ \\
\hline $61-70$ & 26 & $8.55 \%$ \\
\hline $71-80$ & 2 & $0.65 \%$ \\
\hline $81-90$ & 3 & $0.65 \%$ \\
\hline Total & $\mathbf{3 0 5}$ & \\
\hline
\end{tabular}

Table-2: Distribution of lesions as per tissue involved and gender.

\begin{tabular}{|l|c|c|c|}
\hline Tissue & Male & Female & Total \\
\hline Thyroid & 4 & 63 & 67 \\
\hline Salivary glands & 10 & 8 & 18 \\
\hline Skin and subcutaneous tissue & 8 & 9 & 17 \\
\hline Lymph node & 125 & 78 & 203 \\
\hline Total & $\mathbf{1 4 7}$ & $\mathbf{1 5 8}$ & $\mathbf{3 0 5}$ \\
\hline
\end{tabular}

Pathology Update: Tropical Journal of Pathology \& Microbiology Available online at: www.pathologyreview.in 573 | P a g e 


\section{Original Research Article}

Table-3: Distribution of various Lymph node lesions

\begin{tabular}{|l|c|c|c|}
\hline Lesions & Male & Female & Total \\
\hline Tuberculosis & 37 & 46 & 83 \\
\hline Reactive lymphadenitis & 14 & 16 & 30 \\
\hline Acute suppurative Inflammation & 18 & 05 & 23 \\
\hline Chronic non specific inflammation & 06 & 03 & 09 \\
\hline Lymphoma & 00 & 00 & 00 \\
\hline Metastasis & 50 & 08 & 58 \\
\hline Total & $\mathbf{1 2 5}$ & $\mathbf{7 8}$ & $\mathbf{2 0 3}$ \\
\hline
\end{tabular}

Among the diagnostic outcome, higher incidences of lesion are in the neck region than in the head region. Lymph node involvement $203(66.56 \%)$ was common than any other lesion. Among 203 cases of lymph node lesions, 83 cases $(40.89 \%)$ were having tuberculous inflammation, $30(14.78 \%)$ were having reactive lymphadenitis, $23(11.33 \%)$ cases were acute suppurative inflammation and $9(4.43 \%)$ cases were having chronic non specific lymphadenitis and 58 (28.57 $\%$ ) were having metastatic carcinoma (Metastatic Squamous cell carcinoma) (Table 3).

Table-4: Distribution of various Thyroid lesions

\begin{tabular}{|l|c|c|c|}
\hline Lesions & Male & Female & Total \\
\hline Thyroiditis & 1 & 18 & 19 \\
\hline Colloid Goitre & 1 & 41 & 42 \\
\hline Follicular Carcinoma & 0 & 2 & 3 \\
\hline Medullary Carcinoma & 1 & 2 & 1 \\
\hline Papillary Carcinoma & 1 & 0 & $\mathbf{6 7}$ \\
\hline Total & $\mathbf{4}$ & $\mathbf{6 3}$ & 2 \\
\hline
\end{tabular}

Out of 67 cases of thyroid lesion, 63 cases (94.03\%) were females and 4 cases $(5.97 \%)$ were males. 42 cases $(62.69 \%)$ were of colloid goiter with cystic changes. 19 cases $(28.36 \%)$ were of Hashimoto's Thyroiditis and lymphocytic thyroiditis and 6 cases $(8.96 \%)$ malignant thyroid carcinoma (Table 4$)$.

Table-5: Distribution of various salivary lesions

\begin{tabular}{|l|c|c|c|}
\hline Lesions & Male & Female & Total \\
\hline Sialadenitis & 03 & 05 & 08 \\
\hline Pleomorphic adenoma & 04 & 01 & 05 \\
\hline Warthin's tumor & 02 & 00 & 02 \\
\hline Oncocytoma & 00 & 01 & 01 \\
\hline Mucoepidermoid Carcinoma & 01 & 01 & 02 \\
\hline Total & $\mathbf{1 0}$ & $\mathbf{0 8}$ & $\mathbf{1 8}$ \\
\hline
\end{tabular}

Out of the 18 salivary gland lesions, 5cases (27.78\%) were of Pleomorphic Adenoma, 2 cases (11.11\%) was Warthin's tumor, 8 cases $(44.44 \%)$ was of chronic sialadenitis and 2 cases $(11.11 \%)$ were malignant lesions (Table 5).

Table-6: Distribution of various skin and subcutaneous lesions

\begin{tabular}{|l|c|c|c|}
\hline Lesions & Male & Female & Total \\
\hline Lipoma & 04 & 02 & 06 \\
\hline Keratinous cyst & 03 & 05 & 08 \\
\hline Infected cyst & 01 & 00 & 01 \\
\hline Brachial Cyst & 00 & 01 & 01 \\
\hline Benign Adnexal tumor & 00 & 01 & 01 \\
\hline Total & $\mathbf{0 8}$ & $\mathbf{0 9}$ & $\mathbf{1 7}$ \\
\hline
\end{tabular}

Out of 17 cases of skin and subcutaneous lesions 6 cases (35.29\%) were Lipoma, 8 cases (47.06\%) were Keratinous and epidermal cysts, 1 case $(5.88 \%)$ was brachial cyst, 1 case $(5.88 \%)$ was Benign adnexal tumor and 1 case $(5.88 \%)$ was infected cyst (Table 6). 


\section{Original Research Article}

\section{Discussion}

Fine needle aspiration cytology is one of the most accessible technique for head and neck lesions. The most common diagnosis obtained in our study was of tuberculosis lymphadenitis in $40.89 \%$ (83 cases) of cases. It was seen in all the age groups. It was common in females compared to males.

Metastatic deposits in lymph node was diagnosed in $28.57 \%$ (58 cases). It was common in males compared to females. The most common malignancy encountered was that of squamous cell carcinoma deposits. The smear from these cases were highly cellular and showed pleomorphic squamous epithelial cells arranged in loose cohesive clusters and singles. These cells were highly pleomorphic with very high $\mathrm{N}$ : C ratio and prominent nucleoli. Background showed keratinous material with necrosis. However few of the malignant squamous cell carcinoma deposits showed cystic change where we aspirated a fluid material in FNAC. Few of the cases were adenocarcinoma where cells were arranged predominantly in glandular pattern with vacuolated cytoplasm. 5.90\% (18 cases) were salivary gland lesions in which 18 were benign and 2 were low grade mucoepidermoid carcinoma. Smears from the mucoepidermoid carcinoma cases showed mucus, intermediate and squamous cells. The nucleus were relatively bland with prominent nucleoli in few cells, Background showed debritic dirty material.

FNAC is a simple inexpensive method to diagnose the most significant lesions encountered in clinical practice. Though open biopsy is gold standard in lymph node lesions, FNAC is a simple out-patient procedure where diagnosis is obtained fast and reduces the cost of hospitalization to the patients. It is the technique which has high degree of accuracy. However doubtful lesions should always be correlated in biopsy specimen study. Further immunohistochemistry and other molecular diagnostic methods helps in arriving the definite diagnosis. There no complications of Fnac procedure in head and neck lesions. There are no reported cases of spread of tumor through sinus tract in cases of malignancy.

Study done by Rajyalakshmi et al in Kakinada found that out of 360 cases of head and neck tumors, $39 \%$ were from soft tissue, $38 \%$ were from lymph node and $19 \%$ were of salivary gland origin. $4 \%$ of adnexal lesions were also noticed [10]. Study done by Sreedevi et al [11] also coincided with our study where out of 304 cases studied. $50 \%$ of head neck lesions were from lymph node and in that common lesion seen was reactive lymphadenitis next was thyroid lesions. In thyroid lesions the commonest diagnosis they arrived was of goiter and hashimotos thyroiditis. The salivary gland lesions they encountered was pleomorphic adenoma and one case of basal cell adenoma. They did not document any malignant salivary gland tumor. Whereas in our study we got 3 cases of salivary gland malignancies. The soft tissue lesions they documented was of epidermal cysts and lipoma.

The number of cases studied coincided with our study of 50 cases in a study done by Yoshida et al [13] where they found that TB lymphadenitis was seen in $36 \%$, reactive lymphadenitis in $18 \%$ of cases. Followed by malignant neoplasms and non neoplastic lesions. Anne R Wilkinson et al in the year 2012 did study on FNAC diagnosis of lymph node malignancies and concluded that diagnostic accuracy of metastatic lesions were $97 \%$, for lymphomas it was $82 \%$ with a sensitivity of $97 \%$ and specificity of $100 \%$ [14].

Rathore and team in Panacea conducted the study on head and neck masses on 756 cases. Lymph node swellings were more common followed by thyroid, skin and soft tissue lesions. Salivary gland lesions were least noticed in their study [12].

Table-7: Showing comparison of distribution of head and neck lesions between our study and other national and international studies.

\begin{tabular}{|l|c|c|c|}
\hline & Lymph node \% & Salivary gland \% & Soft tissue \% \\
\hline Our study & 66.56 & 5.90 & 5.57 \\
\hline Shobha [9] & 86 & 12 & 02 \\
\hline Rajyalakshmi[10] & 38 & 19 & 39 \\
\hline Sreedevi[11] & 50 & 10 & 10 \\
\hline Rathore[12] & 75 & 15 & 10 \\
\hline
\end{tabular}

This table explains the comparison of our study and other studies in distribution of lesions. It is observed that lymph nodes are the commonly encountered lesions. Followed by Salivary gland and than soft tissue lesions. However in study done by Rajyalakshmi [10] the soft tissue lesions are more competed to salivary gland lesions.

Pathology Update: Tropical Journal of Pathology \& Microbiology Available online at: www.pathologyreview.in 575 | P a g e 
Original Research Article

Table-8: Comparison of results of various studies

\begin{tabular}{|l|c|c|c|c|c|}
\hline & Our study & $\begin{array}{c}\text { Shreedevi et al } \\
{[\mathbf{1 1}] \mathbf{( 2 0 1 6 )}}\end{array}$ & $\begin{array}{c}\text { Patel DN et al } \\
{[\mathbf{1 6}] \mathbf{( 2 0 1 5 )}}\end{array}$ & $\begin{array}{c}\text { Muddegowda et al } \\
{[\mathbf{1 5}] \mathbf{( 2 0 1 4 )}}\end{array}$ & $\begin{array}{c}\text { Bhagat et al } \\
{[\mathbf{1 7 ]}(\mathbf{2 0 1 3})}\end{array}$ \\
\hline Location & India & India & India & India & India \\
\hline Duration & 8 months & 1 year & 1 year & 8 monts & 1 year \\
\hline No. of patients & 305 & 304 & 250 & & -- \\
\hline M:F ratio & $0.48: 1$ & $1: 2.1$ & --- & Thyroid & Lymphnode \\
\hline $\begin{array}{l}\text { Predominant } \\
\text { sites }\end{array}$ & Lymphnode & Lymphnode & Lymphnode & & \\
\hline
\end{tabular}

Table-9: Sex wise distribution of cases

\begin{tabular}{|c|c|c|c|}
\hline Study & Number of cases & Male & Female \\
\hline Present Study & 305 & 147 & 158 \\
\hline Shekhar et al $[18]$ & 200 & 114 & 86 \\
\hline
\end{tabular}

\section{Conclusion}

It was concluded from the present study, that Tuberculosis lymphadenitis is the commonest problem in patients presenting with neckswellings in our set-up, followed by malignant neoplasmespecially metastatic carcinoma and Colloid Goitre and Reactive Lymphadenitis. Our study found that FNAC is a simple, quick, inexpensive, andminimally invasive technique to diagnose different types of head and neck swellings. It could differentiate the infective process fromneo-plastic one and avoids unnecessary surgeries. Thus, FNAC can be recommended as a first lineof investigation in the diagnosis of head and neckswellings.

Moreover, nowadays, with increasingcost of medical facilities, any technique which speeds up the process of diagnosis, limits the physical and psychological trauma to the patient, and saves the expenditure of hospitalization, will be of tremendous value. It may also help the surgeon to select, guide, and modify surgical planning in patients requiring surgery.

\section{Contribution from the Author}

- Dr. Mayuree H. Modi: Data collection, analysis and preparation of manuscript.

- Dr. Mayur J. Kokani: Analysis and preparation of manuscript \& critical revision.

Funding: Nil, Conflict of interest: None initiated Permission from IRB: Yes

\section{References}

1. Tariq Ahmad, Mohammad Naeem, Siddique Ahmad, Ambreen Samad, Amir Nasir. Fine Needle Aspiration Cytology (FNAC) and Neck Swellings in The Surgical Outpatient. J Ayub Med Coll Abbottabad, 2008; 20(3): 30-32.
2. Chauhan Setal, Dharmendra Rathod, D. S. Joshi. FNAC of Swellings of Head and Neck Region. Indian Journal of Applied Basic Medical Sciences, 2011;13:1-6.

3. Gamba PG, Messineo A, Antoniello LM, et al. A simple exam to screen superficial masses: fine-needle aspiration cytology. Med Pediatr Oncol. 1995 Feb; 24 (2):97-9.

4. Lee JC, Siow JK. Thyroid surgery--the Tan Tock Seng Hospital otolaryngology experience. Ann Acad Med Singapore. 2002 Mar;31(2):158-64.

5. Afridi S, Malik K, Waheed I. Role of fine needle aspiration biopsy and cytology in breast lumps. J Coll Physicians Surg Pak, 1995; 5: 75-7.

6. Burnand KG, Young AE, Lucas J, Rrolands BJ, Scholefield J. The new Aird's companion in surgical studies. $3^{\text {rd }}$ edition, China: Elsevier; 2005.

7. Layfield LJ. Fine-needle aspiration of the head and neck. Pathology (Phila). 1996;4(2):409-38.

8. Kirk RM, Ribbans WJ. Clinical Surgery in General. 4th edition, Edinburgh: Elsevier; 2004.

9. Shobha SN, Rajashekar YR. Role of Fine needle aspiration cytology in Head and neck lesions Indian Journal of Pathology and Oncology, July-September 2017;4(3):408-412

10. Rajyalakshmi R, Rajeshwari R, Satyanarayana ROA, Vijaya Bhaskar R. Fine needle aspiration of Head and neck tumours (excluding Thyroid lesions) in correlation with Histopathology and Immunohistochemistry- a retrospective study. Journal of Medical and Dental sciences.2016;15:26-32. 


\section{Original Research Article}

11. Sreedevi P, Kishore Kumar, Parankusa N C. Diagnostic Role of FNAC in evaluation of Head and Neck lesions. Journal of Medical and Dental sciences.2016;11-13.

12. Rathore H, Jethani N, Panchori G, Bansod P. Ratnawat Kalpana. Cytomorphology of Head and Neck lesions: A study in tertiary care hospital. Panacea journal of Medical Sciencws. 2015;3:234-39.

13. Yoshida E, Joaquin G, David W, Allen M. Salivary gland malignancies in children. International journal of Paediatric Otorhinolaryngology. 2014;78:174-178.

14. Wilkinson AR, Mahore SD, Maimoon SA. FNAC in the diagnosis of lymph node malignancies: A simple and sensitive tool. Indian J Med Paediatr Oncol. 2012 Jan;33(1):21-4. doi: 10.4103/0971-5851.96964.

15. Muddegowda PH, Srinivasan S, Lingegowda JB, et al. Spectrum of cytology of neck lesions: comparative study from two centers. J Clin Diagn Res. 2014 Mar; 8 (3): 44-5. doi: 10.7860/JCDR/2014/7250.4102. Epub 2014 Mar 15.

16. Patel DN, Patel PB, Patel HV, Gandhi TJ. Fine needle aspiration cytology role in head and neck lesions. IAIM, 2015; 2(8):99-104.

17. Bhagat VM, Tailor HJ, Saini PK, Dudhat RB, Makawana GR, Unjiya RM. Fine Needle Aspiration Cytology In Nonthyroidal HeadAnd Neck Masses-A Descriptive Study In Tertiary Care Hospital. National Journal Of Medical Research 2013; volume 3 (3): 273-76.

18. Himanshu Shekhar, Ashmeet Kaur, Pallav Agrawal, ArunaPancharia, Poojaba Jadeja, Fine needle aspiration cytology in head and neck swellings: a diagnostic and therapeutic procedure, International Journal of Research in Medical Sciences Int J Res Med Sci. 2014 Nov; 2 (4): 1667-1671.

\section{How to cite this article?}

Modi M.H. Kokani M.J., Diagnostic Role of FNAC in Evaluation of Head and Neck Lesions. Trop J Path Micro 2018;4(8):572-577.doi:10.17511/jopm.2018.i08.05. 